\title{
Quantitative Trait Loci Mapping of Resistance to Sugarcane Mosaic Virus in Maize
}

\author{
Xianchun Xia, Albrecht E. Melchinger, Lissy Kuntze, and Thomas Lübberstedt
}

Institute of Plant Breeding, Seed Science, and Population Genetics, University of Hohenheim, 70593 Stuttgart, Germany. Accepted for publication 4 May 1999.

\begin{abstract}
Xia, X., Melchinger, A. E., Kuntze, L., and Lübberstedt, T. 1999. Quantitative trait loci mapping of resistance to sugarcane mosaic virus in maize. Phytopathology 89:660-667.

Sugarcane mosaic virus (SCMV) is an important virus disease of maize (Zea mays) in Europe. In this study, we mapped and characterized quantitative trait loci (QTL) affecting resistance to SCMV in a maize population consisting of $219 \mathrm{~F}_{3}$ or immortalized $\mathrm{F}_{2}$ families from the cross of two European maize inbreds, D32 (resistant) $\times$ D145 (susceptible). Resistance was evaluated in replicated field trials across two environments under artificial inoculation. The method of composite interval mapping was

fragment length polymorphism and 7 mapped microsatellite markers. Genotypic and genotype $x$ environment interaction variances for SCMV resistance were highly significant in the population. Heritabilities ranged from 0.77 to 0.94 for disease scores recorded on seven consecutive dates. Five QTL for SCMV resistance were identified on chromosomes 1, 3, 5, 6, and 10 in the joint analyses. Two major QTL on chromosomes 3 and 6 were detected consistently in both environments. Significant epistatic effects were found among some of these QTL. A simultaneous fit with all QTL in the joint analyses explained between 70 and $77 \%$ of the phenotypic variance observed at various stages of plant development. Resistance to SCMV was correlated with plant height and days to anthesis.
\end{abstract} employed for QTL detection with a linkage map based on 87 restriction
Sugarcane mosaic virus (SCMV) is one of the most important virus diseases of maize (Zea mays L.) and causes serious yield losses in susceptible cultivars (7). In Germany, SCMV is more prevalent than maize dwarf mosaic virus (MDMV) and causes increasing damage to maize (8), while MDMV is a widespread viral disease in the southern U.S. corn belt (24). Taxonomically, SCMV as well as MDMV and wheat streak mosaic virus (WSMV) belong to a group of related pathogenic potyviruses in maize (20). SCMV is naturally transmitted by aphids in a nonpersistent manner. It is not possible to control SCMV directly with chemical means. Likewise, control of the aphid vectors is not effective because of the nonpersistent mode of virus transmission. Therefore, cultivation of resistant maize varieties is the preferable way to control SCMV infections.

Studies on the resistance to MDMV, SCMV, and WSMV have been conducted mainly with U.S. maize germ plasm. In the maize inbred Oh7B, resistance to MDMV is controlled by a single dominant gene (48). McMullen and Louie (37) found a major gene, designated $M d m 1$, that confers resistance to MDMV in Pa405 and is located between restriction fragment length polymorphism (RFLP) markers bnl6.29 and umc 85 on the short arm of chromosome 6 (6S). A more detailed study showed that $M d m 1$ was perfectly cosegregating with the nucleolus organizer region (nor) (54). In the cross $\mathrm{Pa} 405 \times \mathrm{Oh} 28$, three genes (Wsml, Wsm2, and Wsm3) conferred resistance to WSMV $(35,36)$. Additional virus resistance genes in maize were identified on chromosome 1 (Msvl against maize streak virus [MSV]) (61), chromosome 3 (Mv1 against maize mosaic virus [MMV]) (43), and chromosome 6 (HPV against high plains virus) (33).

In a recent study with early-maturing European maize germ plasm, 122 inbreds were screened under both greenhouse and field conditions (21). Three lines (D21, D32, and FAP1360A) were found to be completely resistant to SCMV, MDMV, Johnson grass mosaic virus, and sorghum mosaic virus. Preliminary investigations on the inheritance

Corresponding author: T. Lübberstedt; E-mail address: luebbit@uni-hohenheim.de

Publication no. P-1999-0608-01R

(C) 1999 The American Phytopathological Society indicated that one to three genes conferred resistance to SCMV in different crosses. Two major resistance genes, $\mathrm{Scm} 1$ and $\mathrm{Scm} 2$, mapped to chromosomes $6 \mathrm{~S}$ and 3, respectively (40). Linkage analysis of 40 BC5 progenies derived from the cross FAP1360A $\times$ F7 suggested that $S \mathrm{cml}$ is closely linked with amplified fragment length polymorphism marker E3M8-1 (0.0 centimorgan [cM]) and that Scm2 is located distal of RFLP marker umcl02 (4.4 cM) (63). Because of the small population size employed by these authors, it was neither possible to investigate the gene action of $\mathrm{Scm} 1$ and $\mathrm{Scm} 2$ nor to identify minor resistance genes.

In this study, we mapped quantitative trait loci (QTL) for resistance to SCMV using a population of $\mathrm{F}_{3}$ or corresponding immortalized $\mathrm{F}_{2}\left(\mathrm{IF}_{2}\right)$ families derived from the cross $\mathrm{D} 32 \times \mathrm{D} 145$. Our objectives were to (i) estimate the number and chromosomal position of major and minor genes responsible for SCMV resistance in this cross, (ii) determine their gene action, (iii) identify molecular markers linked to these QTL, and (iv) examine associations between resistance to SCMV and other agronomic traits.

\section{MATERIALS AND METHODS}

Plant materials. Two early-maturing European inbred lines, D145 (flint) and D32 (dent), were crossed in both reciprocal forms to produce a random set of $220 \mathrm{~F}_{3}$ families (population D32 $\times$ D145). A subset of $122 \mathrm{~F}_{3}$ families had the cytoplasm of line D145, and the remaining $98 \mathrm{~F}_{3}$ families had the cytoplasm of D32. For each $\mathrm{F}_{3}$ family, a pool of $20 \mathrm{~F}_{3}$ plants was chosen to generate an $\mathrm{IF}_{2}(9)$ population by randomly crossing $10 \mathrm{~F}_{3}$ plants as females and $10 \mathrm{~F}_{3}$ plants as males. Line D32 is completely resistant to SCMV, whereas line D145 is highly susceptible (21).

Inoculum preparation and inoculation. Virus inoculum for testing resistance against SCMV isolate Seehausen was prepared as described by Fuchs and Grüntzig (7). Young leaves with typical mosaic symptoms of the SCMV-infected maize variety Bermasil were homogenized using 5 volumes of a $0.01-\mathrm{M}$ phosphate buffer at $\mathrm{pH}$ 7.0. Carborundum was added to the sap. During sap preparation and mechanical inoculation, the inoculum was kept at $+4^{\circ} \mathrm{C}$. Plants at the three- to four-leaf stage were mechanically inoculated 
twice at a weekly interval by an airbrush technique with a tractormounted air compressor at a constant pressure of $800 \mathrm{kPa}(8)$.

Agronomic trials. The $\mathrm{F}_{3}$ population derived from the cross D32 $\times$ D145 was evaluated at Eckartsweier (located in the Upper Rhine Valley close to Straßburg, France) in 1996 and at Hohenheim (near Stuttgart, Germany) in 1997 for resistance against SCMV. The experiment included $220 \mathrm{~F}_{3}$ or $\mathrm{IF}_{2}$ families and both parent lines each included as quintuple entries. The 230 entries were grown in a $23 \times 10$ alpha lattice design with two replications (46). Plots consisted of single rows, $0.7 \mathrm{~m}$ apart and $3 \mathrm{~m}$ long. Plots were overplanted and later thinned to a final plant density of nine plants per $\mathrm{m}^{2}$ with a total of 20 plants per row.

Resistance to SCMV was scored beginning 2 weeks after initial inoculation. Virus symptoms were recorded at weekly intervals on seven dates in 1996 and on nine dates in 1997. $F_{3}$ means from the fifth and eighth scorings in 1997 were not used for the combined analyses across environments because they were similar to the fourth and seventh scorings, respectively. The other seven scorings in 1997 were treated as the first to seventh scorings and used for the combined analyses across both years. These seven scorings on seven dates were designated VIR1 to VIR7. The susceptible parent D145 was, by mistake, substituted by the susceptible inbred D408 in the field experiment in 1996.

Plant height (PHT, in centimeters) was measured plotwise as the distance from soil level to the lowest tassel branch of a representative plant. Days to anthesis (DTA) refers to the number of days from sowing to anthesis for $50 \%$ of the plants in each plot.

Leaf collection and DNA extraction. Leaves were harvested from 20 plants per $\mathrm{F}_{3}$ family after the second SCMV inoculation in 1996. Subsequently, equal amounts of leaf material from each plant were bulked to determine the marker genotype of the corre- sponding parental $F_{2}$ plant. Harvested leaves were freeze-dried and ground to powder. DNA extraction was performed according to the cetyltrimethylammonium bromide method (11).

RFLP analyses. Genomic DNA was digested with restriction enzymes EcoRI, HindIII, EcoRV, BamHI, and BglI. The resulting DNA fragments were separated by electrophoresis on $0.8 \%$ agarose gels and vacuum-blotted onto nylon membranes. Hybridization was carried out by using a nonradioactive detection method described by Hoisington et al. (11). A total of 105 maize DNA probes from the standard probe collection available at the University of Missouri, Columbia, was employed for screening parents D32 and D145. The resulting 76 polymorphic RFLP probes were applied to the $\mathrm{F}_{3}$ population.

Simple sequence repeat (SSR) analyses. Additionally, seven mapped microsatellite SSR markers were analyzed (Fig. 1). Sequences of these primers were obtained from the maize database $(55,56)$ and synthesized by Amersham Pharmacia Biotech (Freiburg, Germany). Polymerase chain reaction amplification and MetaPhor gel electrophoresis (FMC BioProducts, Rockland, ME) were performed according to Lübberstedt et al. (26).

Segregation and linkage analyses. Segregation at each marker locus was checked for deviations from Mendelian segregation ratios (1:2:1 or $3: 1)$ and allele frequency 0.5 by $\chi^{2}$ tests (60). Taking into account that multiple tests were performed, appropriate type I error rates were determined by the sequentially rejective Bonferroni procedure described by Holm (12). Estimates of the proportion of parental genome for each individual were obtained according to Paterson et al. (45). Linkage analysis of RFLP and SSR markers was conducted with Mapmaker 3.0b (22) software using Haldane's mapping function. The threshold used for linkage analyses was set to a $\log _{10}$ odds ratio (LOD) value of 3.0. A total of 87 RFLP and 7 SSR
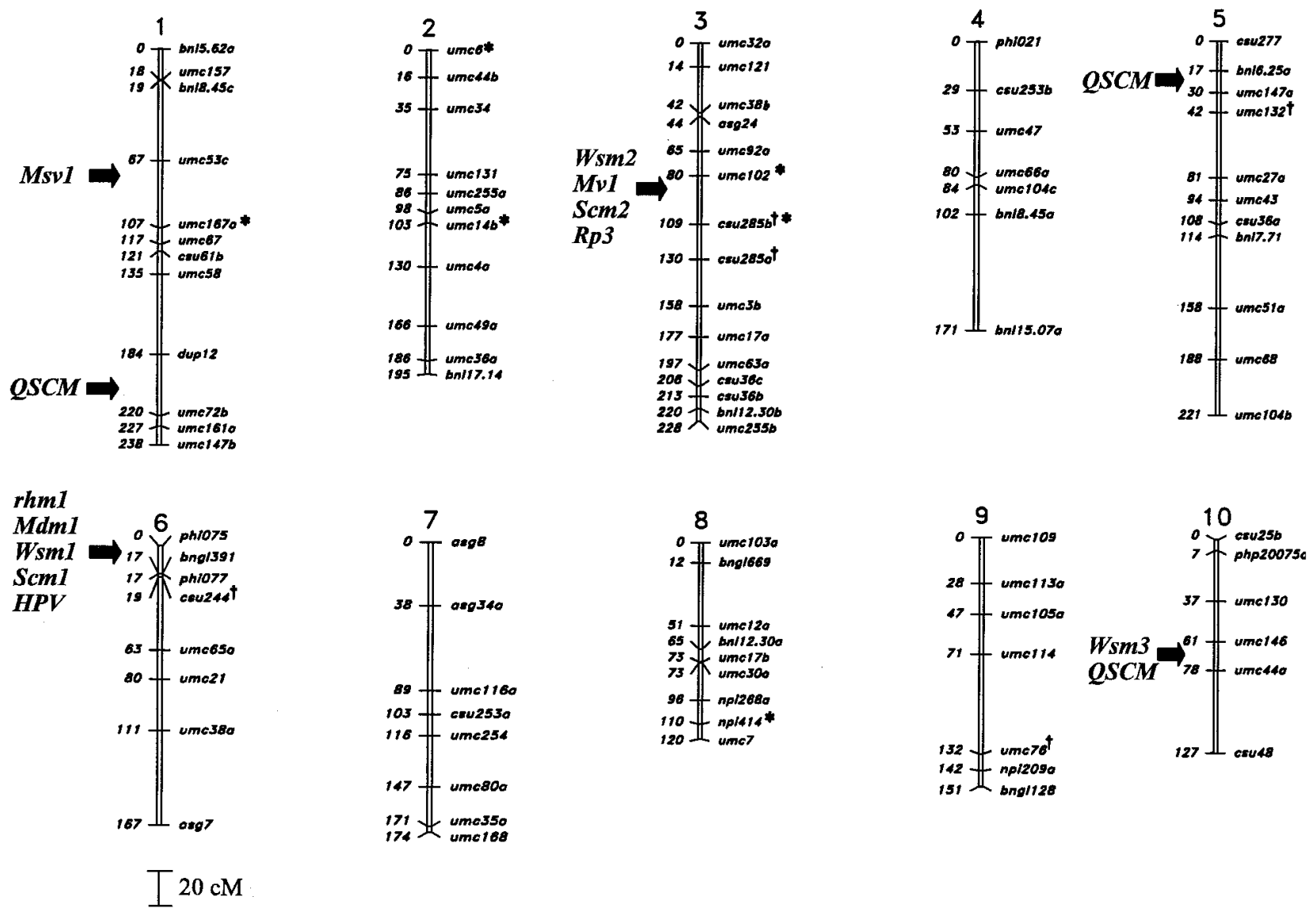

Fig. 1. Combined linkage map for 87 restriction fragment length polymorphism and 7 microsatellite markers based on $219 \mathrm{~F}_{3}$ families derived from the cross $\mathrm{D} 32 \times \mathrm{D} 145$ and approximate map position of five quantitative trait loci (QTL) (including $5 \mathrm{~cm} 1$ and $S \mathrm{~cm} 2$ ) for resistance to sugarcane mosaic virus (SCMV) found in this study and other resistance genes against various viral and fungal diseases of maize reported in the literature. Three minor QTL for resistance to SCMV are indicated by QSCM. $†=$ Map positions not in agreement with those previously published (44). * Genotype frequencies deviated significantly from the Mendelian expectations (1:2:1 or 3:1). 
agreement with published maps for temperate maize germ plasm, except for five loci that mapped to different positions (Fig. 1). The 94 markers span a map distance of $1,799 \mathrm{cM}$ with an average interval length of $21.4 \mathrm{cM}$. All loci were significantly linked (LOD > 3.0) to one of the 10 linkage groups.

Phenotypic data. Both parents D32 and D145 differed significantly $(P<0.01)$ for resistance to SCMV in 1997 (Fig. 2). D32 expressed almost complete resistance to SCMV with only $1 \%$ infected plants, while $100 \%$ of all plants of D145 were diseased at VIR7. The mean proportion of infected plants across all $219 \mathrm{~F}_{3}$ families increased from $8 \%$ on the first scoring date (VIR1) to $54 \%$ on the final scoring date (VIR7) averaged across both environments (Table 1). The correlation among $\mathrm{F}_{3}$ family means between both environments for VIR7 was 0.88 . No significant $(P>0.05)$ difference existed between the mean of both parents $(\bar{P})$ and the mean of all $219 \mathrm{~F}_{3}$ families $\left(\bar{F}_{3}\right)$ for VIR7 in 1997. The contrast between the two subgroups of $\mathrm{F}_{3}$ families differing in the reciprocal form of the parental $\mathrm{F}_{1}$ cross revealed significant $(P<0.05)$ cytoplasmic effects only for PHT and DTA, but not for SCMV resistance (VIR1 to VIR7).
Genotypic variances ( $\left.\hat{\sigma}_{g}^{2}\right)$ were highly significant $(P<0.01)$ for SCMV resistance on all scoring dates (Table 1). Estimates of $\hat{\sigma}_{g e}^{2}$ were also significant for these traits, but significantly smaller than $\hat{\sigma}_{g}^{2}$. Heritabilities for VIR1 to VIR7 ranged from 0.77 to 0.94 .

Phenotypic correlations were highly significant $(P<0.01)$ between resistance to SCMV and various agronomic traits such as PHT and DTA (Table 2). Correlations were highest $\left(\hat{r}_{p} \geq 0.70\right)$ among VIR1, VIR5, and VIR7. These traits also showed moderate correlations with PHT $\left(-0.44 \leq \hat{r}_{p} \leq-0.36\right)$ and DTA $\left(0.46 \leq \hat{r}_{p} \leq 0.49\right)$.

QTL analyses. In the joint analyses for SCMV resistance, four, eight, seven, nine, and nine markers were used as cofactors for VIR1, VIR2, VIR3, VIR5, and VIR7, respectively. A similar set of cofactors were applied to identify QTL in individual environments. Five QTL were identified on chromosomes 1, 3, 5, 6, and 10 with significant effects on resistance to SCMV in the joint analyses across both years (Table 3). All QTL alleles conferring resistance to SCMV were contributed by the resistant parent D32, except for the QTL detected on chromosome 10. The largest QTL detected at all stages of plant development was located on chromosome $6 \mathrm{~S}$ and explained between 56 and $47 \%$ of $\hat{\sigma}_{p}^{2}$ for VIR1

TABLE 3. Parameters associated with putative quantitative trait loci (QTL) significantly affecting resistance to sugarcane mosaic virus on various scoring dates (VIR1, VIR2, VIR3, VIR5, and VIR7) in $219 \mathrm{~F}_{3}$ families of the maize population D32 $\times$ D145 measured in two environments

\begin{tabular}{|c|c|c|c|c|c|c|c|c|c|c|c|c|c|c|c|c|}
\hline \multirow[b]{2}{*}{$\operatorname{Bin}^{t}$} & \multirow[b]{2}{*}{ Parameter $^{\mathrm{u}}$} & \multicolumn{3}{|c|}{ VIR $1^{v}$} & \multicolumn{3}{|c|}{ VIR2 } & \multicolumn{3}{|c|}{ VIR3 } & \multicolumn{3}{|c|}{ VIR5 } & \multicolumn{3}{|c|}{ VIR7 } \\
\hline & & EWE96 $^{\mathrm{W}}$ & HOH97 & Comb & EWE96 & HOH97 & Comb & EWE96 & HOH97 & Comb & EWE96 & HOH97 & Comb & EWE96 & HOH97 & Comb \\
\hline 1.08 & $\begin{array}{l}\mathrm{a}_{1} \\
\mathrm{~d}_{1} \\
R^{2}{ }_{1} \\
\mathrm{a}_{1} \times \mathrm{E} \\
\mathrm{d}_{1} \times \mathrm{E}\end{array}$ & $\begin{array}{c}1 \\
-10^{* * x} \\
7\end{array}$ & $\begin{array}{c}0 \\
-16^{* *} \\
7\end{array}$ & $\begin{array}{c}0 \\
-13^{* *} \\
8 \\
\mathrm{~ns} \\
\mathrm{~ns}\end{array}$ & & $\begin{array}{c}2 \\
-27^{* *} \\
6\end{array}$ & $\begin{array}{c}1 \\
-19 * * \\
7 \\
\mathrm{~ns} \\
*\end{array}$ & & $\begin{array}{c}3 \\
-31^{* *} \\
10\end{array}$ & $\begin{array}{c}2 \\
-25^{* *} \\
10 \\
\mathrm{~ns} \\
\mathrm{~ns}\end{array}$ & & $\begin{array}{c}1 \\
-26^{* *} \\
7\end{array}$ & $\begin{array}{c}0 \\
-22 * * \\
7 \\
\mathrm{~ns} \\
\mathrm{~ns}\end{array}$ & $\begin{array}{c}-1 \\
-23^{* *} \\
6\end{array}$ & $\begin{array}{c}2 \\
-24^{* *} \\
6\end{array}$ & $\begin{array}{c}0 \\
-23^{* *} \\
7 \\
\mathrm{~ns} \\
\mathrm{~ns}\end{array}$ \\
\hline $3.04 / 3.05$ & $\begin{array}{l}\mathrm{a}_{3} \\
\mathrm{~d}_{3} \\
R^{2}{ }_{3} \\
\mathrm{a}_{3} \times \mathrm{E} \\
\mathrm{d}_{3} \times \mathrm{E}\end{array}$ & & & & $\begin{array}{l}4^{*} \\
3 \\
7\end{array}$ & $\begin{array}{c}10^{* * *} \\
-15^{* *} \\
7\end{array}$ & $\begin{array}{c}7 * * \\
-7 \\
7 \\
* \\
\mathrm{~ns}\end{array}$ & $\begin{array}{l}14 * * \\
0 \\
18\end{array}$ & $\begin{array}{l}18 * * \\
-7 \\
17\end{array}$ & $\begin{array}{l}16^{* * *} \\
-4 \\
18 \\
\mathrm{~ns} \\
\mathrm{~ns}\end{array}$ & $\begin{array}{l}22 * * \\
-9 \\
25\end{array}$ & $\begin{array}{l}20 * * \\
-8 \\
20\end{array}$ & $\begin{array}{l}22 * * \\
-7 \\
27 \\
\text { ns } \\
\text { ns }\end{array}$ & $\begin{array}{l}24 * * \\
-9 \\
27\end{array}$ & $\begin{array}{l}24 * * \\
-10 \\
22\end{array}$ & $\begin{array}{c}24 * * \\
-10 \\
28 \\
\text { ns } \\
\text { ns }\end{array}$ \\
\hline 5.01 & $\begin{array}{l}\mathrm{a}_{5} \\
\mathrm{~d}_{5} \\
R^{2}{ }_{5} \\
\mathrm{a}_{5} \times \mathrm{E} \\
\mathrm{d}_{5} \times \mathrm{E}\end{array}$ & & & & & & & & & & $\begin{array}{c}5^{*} \\
-4 \\
7\end{array}$ & & $\begin{array}{c}4^{* *} \\
-6 \\
6 \\
\text { ns } \\
\text { ns }\end{array}$ & $\begin{array}{l}6^{* *} \\
-6 \\
7\end{array}$ & $\begin{array}{c}4^{*} \\
-10 \\
6\end{array}$ & $\begin{array}{c}5^{* * *} \\
-8 \\
8 \\
\mathrm{~ns} \\
\mathrm{~ns}\end{array}$ \\
\hline 10.05 & $\begin{array}{l}\mathrm{a}_{10} \\
\mathrm{~d}_{10} \\
R^{2}{ }_{10} \\
\mathrm{a}_{10} \times \mathrm{E} \\
\mathrm{d}_{10} \times \mathrm{E}\end{array}$ & $\begin{array}{l}-5^{* *} \\
-2 \\
20\end{array}$ & & $\begin{array}{l}-3 * * \\
2 \\
8 \\
* * \\
\mathrm{~ns}\end{array}$ & & & & & & & & & & & & \\
\hline Total & $\begin{array}{l}R^{2 \mathrm{y}} \\
\text { Epistasis } \\
\mathrm{d}_{1} \times \mathrm{a}_{6} \\
\mathrm{~d}_{1} \times \mathrm{d}_{6} \\
\mathrm{a}_{3} \times \mathrm{a}_{6} \\
\mathrm{a}_{3} \times \mathrm{d}_{6} \\
\mathrm{a}_{6} \times \mathrm{a}_{10}\end{array}$ & $-7 * *$ & $\begin{array}{c}49 \\
-29^{* *} \\
36^{*}\end{array}$ & $\begin{array}{c}62 \\
-22 * *\end{array}$ & $16^{*}$ & 74 & 76 & $27 *$ & $\begin{array}{c}66 \\
-78^{*}\end{array}$ & 74 & $36^{* *}$ & $\begin{array}{c}64 \\
-87^{*}\end{array}$ & $\begin{array}{r}-14 * * \\
32 * *\end{array}$ & $39 * *$ & $\begin{array}{c}60 \\
-93^{*} \\
-18^{* *}\end{array}$ & $\begin{array}{r}71 \\
\\
-16^{* *} \\
37 * *\end{array}$ \\
\hline
\end{tabular}

${ }^{\mathrm{t}}$ Chromosomes dissected into Bin regions and QTL positions based on the marker linkage map (Fig. 1) and Neuffer et al. (44) and Gardiner et al. (9). A Bin is a chromosome region flanked by core markers. These core (RFLP) markers have been selected to cover most of the 10 maize chromosomes. The average distance of neighboring core markers is about $20 \mathrm{cM}$. These core markers serve as a kind of "reference marker" for comparison across different mapping studies.

${ }^{\mathrm{u}} \mathrm{a}=$ Additive effect and $\mathrm{d}=$ dominance effect of the QTL. A positive sign of additive effects reflects that QTL alleles increasing resistance were contributed by parent D32. $R^{2}$ estimates the proportion of the phenotypic variance (\%) explained by the detected QTL. a $\times$ Eand $\mathrm{d} \times \mathrm{E}=\mathrm{Interaction}$ between QTL and environment for the a and d effect, respectively.

$\checkmark$ All values are percentages.

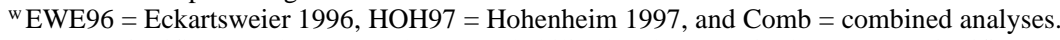

$\mathrm{x} *, * *=$ Significant at the 0.05 and 0.01 probability level, respectively; $\mathrm{ns}=$ not significant $(P>0.05)$.

y Estimates of total $R^{2}$ obtained by a simultaneous fit of all putative QTL affecting the respective trait using a model with additive and dominance effects.

${ }^{\mathrm{z}}$ Estimates of total $R^{2}$ obtained by a simultaneous fit of all putative QTL affecting the respective trait using a model including additive, dominance, and epistatic effects. 
to VIR7. Another large QTL on chromosome 3 was identified from the second to seventh scoring (VIR2 to VIR7) with increasing $R^{2}$ values; it accounted for $28 \%$ of $\hat{\sigma}_{p}^{2}$ at VIR7. These two large QTL were detected consistently in both environments (Table 3). One minor QTL on chromosome 1 was detected on all SCMV scoring dates in the joint analyses and explained between 7 and $10 \%$ of $\hat{\sigma}_{p}^{2}$ at various stages of plant development. Another minor QTL on chromosome 5 was detected from the fifth to seventh scoring and explained 6 to $8 \%$ of $\hat{\sigma}_{p}^{2}$. One minor QTL on chromosome 10 was identified at the first scoring (VIR1) and explained $8 \%$ of $\hat{\sigma}_{p}^{2}$. The three minor QTL were only detected in one environment on some of the SCMV scoring dates. A simultaneous fit with all QTL, using a model with additive and dominance effects, explained between 62 and $76 \%$ of $\hat{\sigma}_{p}^{2}$ in the joint analyses. Extending this model for digenic epistatic effects increased the $R^{2}$ values only marginally, except for VIR1. Significant digenic epistatic effects were found between the two major QTL on chromosomes $6 \mathrm{~S}$ and 3 for VIR2, VIR5, and VIR7 and between the major QTL on chromosome 6S and the two minor QTL on chromosomes 1 and 10 (Table 3). The major QTL on chromosomes $6 \mathrm{~S}$ and 3 showed significant additive and dominance gene effects, whereas the two QTL on chromosomes 5 and 10 displayed only additive gene effects. The minor QTL on chromosome 1 displayed overdominance. Significant $(P<0.05)$ QTL $\times$ E interactions were found for four QTL on certain dates of SCMV scores (Table 3 ).

\section{DISCUSSION}

Genetic foundation of resistance to SCMV. A previous study of SCMV resistance in a $\mathrm{F}_{2}$ population of the cross D145 $\times$ D32 gave evidence for two major resistance genes ( $\mathrm{Scm} 1$ and $\mathrm{Scm} 2$ ) on chromosomes $6 \mathrm{~S}$ and 3 (40). However, the exact position of both resistance genes and their gene action could not be determined because of the limited population size and progeny type. Using $219 \mathrm{~F}_{3}$ families in this study, two QTL with major effects were identified on chromosomes $6 \mathrm{~S}$ and 3 adjacent to markers phi075 and umc102, respectively (Table 3 and Fig. 1), confirming the presence of $\mathrm{Scm} 1$ and Scm 2 in the resistant parent D32. Scm1 explained the largest proportion of $\hat{\sigma}_{p}^{2}$ for all scoring dates and displayed partial dominance for resistance to SCMV based on the estimates of the additive and dominance effect of the QTL (Table 3). The second QTL with major effect $(\mathrm{Scm} 2)$ was not detected at the first scoring, but was of increasing importance from VIR2 to VIR7 as reflected by the $R^{2}$ values (Table 3 ). $S \mathrm{~cm} 2$ also showed partial dominance for resistance to SCMV and explained a smaller proportion of $\hat{\sigma}_{p}^{2}$ than did Scm1 at all scorings (Table 3).

In agreement with our study, several reports on resistance to SCMV, MDMV, and WSMV indicated an oligogenic type of inheritance $(6,36,63)$. However, in most cases, the gene action of the resistance genes was dominant $(6,24,36,48)$, whereas a partially dominant or additive mode of gene action of resistance genes against potyviruses in maize was rarely reported $(23,63)$. Louie et al. $(24$, 25) discussed that the degree of resistance conferred by $M d m 1$ was dependent on the susceptible parent and resistance to MDMV could be strongly influenced by environments. Oligogenic inheritance of virus resistance with partial dominance of resistance genes was also reported for another virus (MSV) in maize (61) and for potyviruses in other crops (4).

The resistance controlled by $S \mathrm{~cm} 2$ was influenced by plant age with an elevated resistance to SCMV at the adult stage. This kind of resistance to potyviruses was also described previously (42,53). Mikel et al. (42) reported that three genes were required for MDMV resistance at the adult stage in maize inbred B68, whereas only two resistance genes were sufficient at early ratings. Kegler and Friedt (18) concluded that resistance to potyvirus $\mathrm{X}$ in potato at the adult stage was related to a reduced content of ribosome and RNA in the leaves.

In addition to major genes, presence of minor genes conferring resistance to SCMV was conjectured for the three maize inbreds
D21, D32, and FAP1360A (40). In support of this hypothesis, we detected QTL on chromosomes 1, 5, and 10 that explained between 6 and $10 \%$ of $\hat{\sigma}_{p}^{2}$ (Table 3). Minor genes were also identified for resistance to MDMV $(16,17)$. Caranta et al. (4) detected several minor QTL associated with resistance to various potyviruses in pepper, and Welz et al. (61) found three QTL with minor effects on resistance to MSV in maize. Kegler and Friedt (18) discussed the effects of minor genes for MDMV resistance that could reduce the rate of infection and virus concentration, prolong the incubation time, and inhibit the movement of viruses in the plant.

In the current study, 34 out of the 94 markers displayed a dominant (3:1) inheritance pattern. The influence of the large number of dominant markers on the results from QTL analyses was evaluated. Three out of the five QTL (on chromosomes 1, 6S, and 10) detected for SCMV resistance were flanked by codominant markers, whereas the other two QTL (on chromosomes 3 and 5) were flanked by one codominant and one dominant marker, respectively. When we deleted the flanking dominant markers, the estimates of additive and dominance effects of the two QTL on chromosomes 3 and 5 were hardly affected and there was no change for the other three QTL on chromosomes 1, 6S, and 10. Hence, the large number of dominant markers did not influence the estimated gene effects of the five detected QTL for resistance to SCMV. However, owing to the reduced power in QTL detection when using dominant instead of codominant markers, some minor QTL might not have been detected in our mapping population.

Epistatic effects. Classical genetic studies have uncovered various examples of epistatic effects on disease resistance (64). With the aid of QTL mapping, epistatic interactions can be related to individual resistance genes. Caranta et al. (5) found a digenic epistasis between two QTL influencing resistance to cucumber mosaic virus in pepper. Van Koevering et al. (59) obtained evidence for aa epistatic effects between loci A and B for resistance to wheat spindle streak mosaic virus in wheat. In the current study, significant aa and ad epistatic effects were estimated for VIR7 between the two major QTL (Table 3), but there was only a minor increase in the $R^{2}$ values of this model. This apparent discrepancy can be explained by the high correlation between the coefficients of epistatic and additive or dominance effects in the regression model employed in the QTL analysis. Epistatic effects may arise from interrelated biochemical pathways or dependent physiological and morphological characters, which was confirmed by a detailed study of trichome-mediated insect resistance in potato (3).

Clustering of resistance genes in maize. Resistance genes against different pathogens are often clustered in the same chromosome regions of the maize genome (38). The resistance genes Mdml (MDMV) (36), Wsml (WSMV) (37), and rhml (southern corn leaf blight) (65) were located on the short arm of chromosome $6(6 \mathrm{~S})$. Recently, a resistance gene (HPV) against high plains virus and $S c m l$ against SCMV were also mapped to this region $(33,40)$. Presence of a major resistance gene against SCMV at the position of $\mathrm{Scm} 1$ on chromosome $6 \mathrm{~S}$ in the cross FAP1360A $\times$ F7 was corroborated by $\mathrm{Xu}$ et al. (63). It is unknown whether $\mathrm{Scml}$, $M d m l$, and Wsml are identical and display pleiotropic effects against different potyviruses or are closely linked genes. The U.S. inbred Pa405 as well as the three resistant European lines D21, D32, and FAP1360A conferred resistance against different maize pathogenic potyviruses (21). Furthermore, tests of allelism between Pa405 and D21, D32, or FAP1360A supported the hypothesis that Scml and Mdml or Wsml are identical (40). However, the small sample size (200 plants for each $F_{2}$ population) was not sufficient to detect rare recombination events between closely linked loci resulting in susceptible plants. In agreement with the hypothesis of closely linked but different major resistance genes, Lübberstedt et al. (32) found a few susceptible plants in tests of allelism between the three European resistant inbreds. Furthermore, Xu et al. (63) identified three recombinants between the nor and the Scml gene in a sample of 40 resistant BC5 individuals from the cross 
FAP1360A $\times$ F7, whereas no recombinant was observed between nor and $M d m l$ in 7,650 $\mathrm{F}_{2}$ individuals of the cross pol yl tester $\times$ Pa405 (54). Close linkage rather than pleiotropy of resistance genes has been frequently demonstrated including resistance gene clusters against common rust in maize (13), downy mildew in lettuce (14), and bacterial blight (Pseudomonas syringae pv.) in tomato $(34,50)$. Linkage rather than pleiotropy also seems more likely for resistance genes acting against different pests such as SCMV and southern corn leaf blight.

The second major resistance gene in this study, Scm2, mapped closely to the centromere region of chromosome 3 (Fig. 1 and Table 3), harboring the major resistance genes Rp3 (Puccinia sorghi) (51), Mv1 (MMV) (43), Wsm2 (WSMV) (37), and three QTL for resistance to European corn borer, Fusarium stalk rot (38), and common smut (28). Wsm 2 is different from $M v 1$ because Pa405 is susceptible to MMV (43). However, it is unclear whether Scm2 is identical to Wsm 2 or $M v 1$. Alternatively, the chromosome regions harboring $S \mathrm{~cm} 2$ and Wsm2 (chromosome 3) as well as Scm1, $M d m 1$, and Wsml (chromosome 6) might contain clusters of potyvirus resistance genes.

One QTL with minor effects on SCMV resistance clustered with Wsm3 (WSMV) (37) located on chromosome 10. Hence, reverting to Robertson's (49) hypothesis about the relationship between major genes and QTL, the QTL for SCMV resistance identified in this study might indicate the potential presence of additional major Scm resistance genes in the maize germ plasm. Another QTL with minor effects was mapped on chromosome 5, clustering with one QTL for resistance against northern corn leaf blight (38) and one for common smut (28). The QTL on chromosome 1 mapped to the same position as a QTL for resistance to common smut (31). To resolve the relationship among clustered resistance genes, cloning of these genes is required.

Environmental influence on resistance and QTL $\times \mathbf{E}$ interactions. Resistance against potyviruses in maize is strongly influenced by the environment. In maize inbreds tested for MDMV resistance, Louie et al. (25) found a considerably higher disease incidence in the greenhouse than in the field and hypothesized that the tender greenhouse plants are more easily infected after virus inoculation. In a study of SCMV resistance, a higher proportion of susceptible plants was also identified under greenhouse conditions than in field tests (40). Tu and Ford (57) found an increasing susceptibility of maize to MDMV with increasing temperature. These results suggested that resistance to potyviruses in maize might be a "threshold" character.

Although the two environments hardly differed in the $\mathrm{F}_{3}$ population mean of infected plants in our study, estimates of $\hat{\sigma}_{g e}^{2}$ were highly significant $(P<0.01)$ for all dates of virus scoring and QTL $\times$ E interactions were highly significant $(P<0.01)$ for $S \mathrm{~cm} 1$ at VIR2, VIR5, and VIR7 (Table 3). QTL analyses showed that the additive or dominance effect values of two large QTL differed in two environments at certain SCMV scores and the three minor QTL were not expressed consistently across two environments (Table 3). These findings are in contrast to other QTL mapping studies of virus resistance $(4,5,43,61)$, in which QTL $\times$ E interactions have not been detected. Possible explanations for these contrasting findings are (i) the different pathosystems investigated, (ii) the type of mapping populations evaluated $\left(\mathrm{F}_{3}\right.$ families versus $\mathrm{F}_{2}$ plants or double-haploid lines), and above all, (iii) the biometric procedures and software employed in QTL mapping (39).

Associations between SCMV resistance and agronomic traits. Biotic and abiotic stresses can severely affect the development of the maize plant and cause dramatic physiological and phenotypic changes. In studies of drought stress on maize $(2,47,62)$, PHT decreased under drought conditions. In this study, the reduction in PHT of infected plants was largely explained by one common QTL on chromosome 6S between PHT and VIR7 (Table 2) and one closely linked QTL on chromosome 3 (X. C. Xia, unpublished data). Significant phenotypic correlations were also found between VIR7 and DTA with one common QTL (Table 2). However, for all QTL in common between agronomic traits and SCMV resistance, it remains to be shown whether they are due to pleiotropy or close linkage.

Marker-assisted selection (MAS). Maize lines resistant against SCMV can be efficiently identified with conventional phenotypic selection because artificial inoculation and visual rating of disease symptoms are fairly rapid and highly reproducible. Nevertheless, MAS for improving SCMV resistance might be advantageous because of (i) the oligogenic inheritance of the target trait, (ii) the strong influence of the environment on the expression of SCMV resistance, and (iii) the high costs for resistance evaluation.

In our study, none of the $219 \mathrm{~F}_{3}$ families was completely resistant across both years, corroborating the oligogenic inheritance of SCMV resistance in the cross D32 $\times$ D145. MAS could be used to incorporate all resistance genes, especially also the QTL with minor effects, into one or both maize inbreds to ascertain almost complete resistance of the resulting hybrid. However, a large population size and highly efficient marker system such as multiplexed SSRs would be required in a breeding program, given that the low frequency $\left(0.25^{5}\right)$ of an individual homozygous for the desired alleles at five unlinked loci in a $F_{2}$ population. Since yield reductions are mainly caused by early SCMV or MDMV infection, protection against these potyviruses is required especially at early stages of plant development. Consequently, the SCMV resistance genes located on chromosomes 1, 6, and 10, which are active at VIR1, might be most desirable for MAS. The resistance genes on chromosomes 1 and 6 especially seem to be rather useful for hybrid breeding given their overdominant (chromosome 1) or dominant (chromosome 6) gene action at VIR1 and VIR2 and their large gene effects compared with the resistance gene on chromosome 10 . $S c m 2$ should be useful for suppression of SCMV infection at later stages of plant development.

In conclusion, QTL mapping and MAS might aid breeders to (i) identify QTL with large gene effects consistently expressed across environments; (ii) detect QTL alleles with dominant gene action, simplifying hybrid breeding; and (iii) pyramid these genes into one or both parents of a hybrid. Since MAS requires neither natural infection nor artificial inoculation with SCMV, it allows indirect selection in offseason nurseries before flowering and, hence, could substantially accelerate breeding programs for resistance to SCMV and other diseases in maize.

\section{ACKNOWLEDGMENTS}

The current study was supported by grants from the Deutsche Forschungsgemeinschaft, grant no. LU601/2. We thank T. A. Musket (University of Missouri, Columbia) for providing RFLP probes. We thank G. Tan and F. Oeynhausen for scoring sugarcane mosaic virus symptoms in the field trials, E. Kokai-Kota for her support with the RFLP and SSR analyses, and H. F. Utz for his support in the statistical analyses. We thank F. Mauch and B. Devezi-Savula at Hohenheim as well as the staff at the Plant Breeding Research Station, Eckartsweier, for their technical assistance in conducting the field trials. We also thank the editor and reviewers for their helpful comments and suggestions for improving the manuscript.

\section{LITERATURE CITED}

1. Bohn, M., Khairallah, M. M., Gonzáles-de-León, D., Utz, H. F., Deutsch, J. A., Jewell, D., Mihm, J. A., and Melchinger, A. E. 1996. QTL mapping in tropical maize: I. Genomic regions affecting resistance to sugarcane borer and other traits. Crop Sci. 36:1352-1361.

2. Bolańos, J., and Edmeades, G. O. 1996. The importance of the anthesissilking interval in breeding for drought tolerance in tropical maize. Field Crop Res. 48:65-80.

3. Bonierbale, M. W., Plaisted, R. L., Pineda, O., and Tanksley, S. D. 1994. QTL analysis of trichome-mediated insect resistance in potato. Theor. Appl. Genet. 87:973-987.

4. Caranta, C., Lefebvre, V., and Palloix, A. 1997. Polygenic resistance of pepper to potyviruses consists of a combination of isolate-specific and broad-spectrum quantitative trait loci. Mol. Plant-Microbe Interact. 10: 
872-878.

5. Caranta, C., Palloix, A., Lefebvre, V., and Daubèze, A. M. 1997. QTLs for a component of partial resistance to cucumber mosaic virus in pepper: Restriction of virus installation in host-cells. Theor. Appl. Genet. 94:431-438.

6. Dollinger, E. J., Findley, W. R., and Williams, L. E. 1970. Inheritance of resistance to maize dwarf mosaic virus in maize (Zea mays L.). Crop Sci. 10:412-415.

7. Fuchs, E., and Grüntzig, M. 1995. Influence of sugarcane mosaic virus (SCMV) and maize dwarf mosaic virus (MDMV) on the growth and yield of two maize varieties. J. Plant Dis. Prot. 102:44-50.

8. Fuchs, E., Grüntzig, M., Kuntze, L., Oertel, U., and Hohmann, F. 1996. Zur Epidemiologie der Potyviren des Maises in Deutschland. Pages 43-49 in: Bericht über die 46. Arbeitstagung der Arbeitsgemeinschaft der Saatzuchtleiter im Rahmen der "Vereinigung österreichischer Pflanzenzüchter."

9. Gardiner, J., Coe, E. H., Melia-Hancock, S., Hoisington, D. A., and Chao, S. 1993. Development of a core RFLP map in maize using an immortalized $F_{2}$ population. Genetics 134:917-930.

10. Hallauer, A. R., and Miranda, F. J. B. 1981 Quantitative genetics in maize breeding. Iowa State University Press, Ames.

11. Hoisington, D. A., Khairallah, M. M., and Gonzáles-de-León, D. 1994. Laboratory Protocols: CIMMYT Applied Molecular Genetics Laboratory. CIMMYT, Mexico, DF, Mexico.

12. Holm, S. 1979. A simple sequentially rejective multiple test procedure. Scand. J. Stat. 6:65-70.

13. Hu, G., and Hulbert, S. 1996. Construction of 'compound' rust resistance genes in maize. Euphytica 87:45-51.

14. Hulbert, S. H., and Michelmore, R. W. 1985. Linkage analysis of genes for resistance to downy mildew (Bremia lactucae) in lettuce (Lactuca sativa). Theor. Appl. Genet. 70:520-528.

15. Jansen, R. C. 1993. Interval mapping of multiple quantitative trait loci. Genetics 135:205-211.

16. Johnson, G. R. 1971. Analysis of genetic resistance to maize dwarf mosaic disease. Crop Sci. 11:23-24.

17. Josephson, L. M., and Naidu, B. 1971. Reaction in diallel crosses of corn inbreds (Zea mays L.) to maize dwarf mosaic virus. Crop Sci. 11:664-667.

18. Kegler, H., and Friedt, W. 1993. Resistenz von Kulturpflanzen gegen pflanzenpathogene Viren. Gustav Fischer Verlag, Jena, Germany.

19. Knapp, S. J., Stroup, W. W., and Ross, W. M. 1985. Exact confidence intervals for heritability on a progeny mean basis. Crop Sci. 25:192-194.

20. Kuntze, L., Fuchs, E., Grüntzig, M., Schulz, B., Hennig, U., Hohmann, F., and Melchinger, A. E. 1995. Evaluation of maize inbred lines for resistance to sugarcane mosaic virus (SCMV) and maize dwarf mosaic virus (MDMV). Agronomie 15:463-467.

21. Kuntze, L., Fuchs, E., Grüntzig, M., Schulz, B., Klein, D., and Melchinger, A. E. 1997. Resistance of early-maturing European maize germplasm to sugarcane mosaic virus (SCMV) and maize dwarf mosaic virus (MDMV). Plant Breed. 116:499-501.

22. Lander, E. S., Green, P., Abrahamson, J., Barlow, A., Daly, M. J., Lincoln, S. E., and Newburg, L. 1987. An interactive computer package for constructing primary genetic linkage maps of experimental and natural populations. Genomics 1:174-181.

23. Loesch, P. J., and Zuber, M. S. 1967. An inheritance study of resistance to maize dwarf mosaic virus in corn (Zea mays L.). Agron. J. 59:423-426.

24. Louie, R., Findley, W. R., Knoke, J. K., and McMullen, M. D. 1991. Genetic basis of resistance in maize to five maize dwarf mosaic virus strains. Crop Sci. 31:14-18.

25. Louie, R., Knock, J. K., and Findley, W. R. 1990. Elite maize germplasm: Reaction to maize dwarf mosaic and maize chlorotic dwarf viruses. Crop Sci. 30:1210-1215.

26. Lübberstedt, T., Dußle, C., and Melchinger, A. E. 1998. Application of microsatellite from maize to teosinte and other relatives of maize. Plant Breed. 117:447-450.

27. Lübberstedt, T., Klein, D., and Melchinger, A. E. 1998. Comparative quantitative trait loci mapping of partial resistance to Puccinia sorghi across four populations of European flint maize. Phytopathology 88: 1324-1329.

28. Lübberstedt, T., Klein, D., and Melchinger, A. E. 1998. Comparative QTL mapping of resistance to Ustilago maydis across four populations of European flint maize. Theor. Appl. Genet. 97:1321-1330.

29. Lübberstedt, T., Melchinger, A. E., Fähr, S., Klein, D., Dally, A., and Westhoff, P. 1998. QTL mapping in testcross of European flint lines of maize: III. Comparison across populations for forage traits. Crop Sci. 38: 1278-1289.

30. Lübberstedt, T., Melchinger, A. E., Schön, C. C., Utz, H. F., and Klein, D. 1997. QTL mapping in testcross of European flint lines of maize: I. Comparison of different testers for forage yield traits. Crop Sci. 37:921-931.

31. Lübberstedt, T., Xia, X. C., Tan, G., Liu, X., and Melchinger, A. E. QTL mapping of resistance to Sporisorium reiliana in maize. Theor. Appl.
Genet. In press.

32. Lübberstedt, T., Xia, X. C., Xu, M. L., Kuntze, L., and Melchinger, A. E. Inheritance of resistance to SCMV and MDMV in European maize. In: Proc. of the XVth EUCARPIA 1998 General Congress: Genetics and Breeding for Crop Quality and Resistance. G. T. S. Mugnozza, ed. Kluwer Academic Publishers, Dordrecht, the Netherlands. In press.

33. Marcon, A., Kaeppler, S. M., and Jensen, S. G. 1997. Resistance to systemic spread of high plains virus and wheat streak mosaic virus cosegregation in two $\mathrm{F}_{2}$ maize populations inoculated with both pathogens. Crop Sci. 37:1923-1927.

34. Martin, G. B., Brommonschenkel, S. H., Chunwongse, J., Frary, A., Ganal, M. W., Spivey, R., Wu, T., Earle, E. D., and Tanksley, S. D. 1993. Map-based cloning of a protein kinase gene conferring disease resistance in tomato. Science 262:1432-1436.

35. McMullen, M. D., Jones, M. W., Simcox, K. D., and Louie, R. 1994. Three genetic loci control resistance to wheat streak mosaic virus in the maize inbred Pa405. Mol. Plant-Microbe Interact. 7:708-712.

36. McMullen, M. D., and Louie, R. 1989. The linkage of molecular markers to a gene controlling the symptom response in maize to maize dwarf mosaic virus. Mol. Plant-Microbe Interact. 2:309-314.

37. McMullen, M. D., and Louie, R. 1991. Identification of a gene for resistance to wheat streak mosaic virus in maize. Phytopathology 81:624-627.

38. McMullen, M. D., and Simcox, K. D. 1995. Genomic organization of disease and insect resistance genes in maize. Mol. Plant-Microbe Interact. 8:811-815.

39. Melchinger, A. E. 1997. Advances in the analysis of data on quantitative trait loci. Pages 773-791 in: International Crop Science II. Oxford IBH Publishing Co., New Delhi, India.

40. Melchinger, A. E., Kuntze, L., Gumber, R. K., Lübberstedt, T., and Fuchs, E. 1998. Genetic basis of resistance to sugarcane mosaic virus in European maize germplasm. Theor. Appl. Genet. 96:1151-1161.

41. Melchinger, A. E., Utz, H. F., and Schön, C. C. 1998. QTL mapping using different testers and independent population samples in maize reveals low power of QTL detection and large bias in estimates of QTL effects. Genetics 149:383-403.

42. Mikel, M. A., D’Arcy, C. J., Rhodes, A. M., and Ford, R. E. 1984. Genetics of resistance of two dent corn inbreds to maize dwarf mosaic virus and transfer of resistance into sweet corn. Phytopathology 74:467-473.

43. Ming, R., Brewbaker, J. L., Pratt, R. C., Musket, T. A., and McMullen, M. D. 1997. Molecular mapping of a major gene conferring resistance to maize mosaic virus. Theor. Appl. Genet. 95:271-275.

44. Neuffer, M. G., Coe, E. H., and Wessler, S. R. 1997. The maize organism: The genome. Pages 33-53 in: Mutants of Maize. Cold Spring Harbor Laboratory Press, Cold Spring Harbor, NY.

45. Paterson, A. H., Damon, S., Hewitt, J. D., Zamir, D., Rabinowitch, H. D., Lincoln, S. E., Lander, C. S., and Tanksley, S. D. 1991 Mendelian factors underlying quantitative traits in tomato: Comparison across species, generations, and environments. Genetics 127:181-197.

46. Patterson, H. D., and Williams, E. R. 1976 A new class of resolvable incomplete block designs. Biometrika 63:83-92.

47. Ribaut, J. M., Jiang, C., Gonzáles-de-León, D., Edmeades, G. O., and Hoisington, D. A. 1997. Identification of quantitative trait loci under drought conditions in tropical maize. 2. Yield components and markerassisted selection strategies. Theor. Appl. Genet. 94:887-896.

48. Roane, C. W., Genter, C. F., and Tolin, S. A. 1977. Inheritance of resistance to maize dwarf mosaic virus (MDMV) in maize. (Abstr.) Proc. Am. Phytopathol. Soc. 4:140.

49. Robertson, D. S. 1985. A possible technique for isolating genic DNA for quantitative traits in plants. J. Theor. Biol. 117:1-10.

50. Salmeron, J. M., Oldroyd, G. E. D., Rommens, C. M. T., Scofield, S. R., Kim, H. C., Lavelle, D. T., Dahlbeck, D., and Staskawicz, B. J. 1996. Tomato Prf is a member of the leucine-rich repeat class of plant disease resistance genes and lies embedded within the Pto kinase gene cluster. Cell 86:123-133.

51. Sanz-Alferez, S., Richter, T. E., Hulbert, S. H., and Bennetzen, J. L. 1995. The Rp3 disease resistance gene of maize: Mapping and characterization of introgressed alleles. Theor. Appl. Genet. 91:25-32.

52. Searle, S. R. 1971. Normality assumptions. Pages 408-419 in: Linear Models. John Wiley \& Sons, New York.

53. Sigvald, R. 1985. Mature-plant resistance of potato plants against potato virus $\mathrm{Y}^{\circ}\left(\mathrm{PVY}^{\circ}\right)$. Potato Res. 28:135-143

54. Simcox, K. D., McMullen, M. D., and Louie, R. 1995. Co-segregation of the maize dwarf mosaic virus resistance gene, $M d m 1$, with the nucleolus organizer region in maize. Theor. Appl. Genet. 90:341-346.

55. Smith, J. S. C., Chin, E. C. L., Shu, H., Smith, O. S., Wall, S. J., Senior, M. L., Mitchell, S. E., Kresovich, S., and Ziegle, J. 1997. An evaluation of the utility of SSR loci as molecular markers in maize (Zea mays L.): Comparisons with data from RFLPS and pedigree. Theor. Appl. Genet. 95:163-173. 
56. Taramino, G., and Tingey, S. 1996. A random set of maize simple sequence repeat markers. Maize Genet. Coop. Newsl. 70:110-111.

57. Tu, J. C., and Ford, R. E. 1969. Effect of temperature on maize dwarf mosaic virus infection, incubation, and multiplication in corn. Phytopathology 59:699-702.

58. Utz, H. F., and Melchinger, A. E. 1996. PLABQTL: A program for composite interval mapping of QTL. J. Quant. Trait. Loci. On-line publication: vol. 2, paper 1. Sponsored by the Crop Science Society of America.

59. Van Koevering, M., Haufler, Z. K., Fulbright, D. W., Isleib, T. G., and Everson, E. H. 1987. Heritability of resistance in winter wheat to wheat spindle streak mosaic virus. Phytopathology 77:742-744.

60. Weir, B. S. 1990. Genetic Data Analysis. Sinauer, Sunderland, MA.

61. Welz, H. G., Schechert, A., Pernet, A., Pixley, K. V., and Geiger, H. H. 1998. A gene for resistance to the maize streak virus in the African
CIMMYT maize inbred line CML202. Mol. Breed. 4:147-154.

62. Westgate, M. E., and Boyer, J. S. 1986. Reproduction at low silk and pollen water potentials in maize. Crop Sci. 26:951-956.

63. Xu, M. L., Melchinger, A. E., Xia, X. C., and Lübberstedt, T. 1999. Highresolution mapping of loci conferring resistance to sugarcane mosaic virus in maize using RFLP, SSR and AFLP markers. Mol. Gen. Genet. 261:574-581.

64. Young, N. D. 1996. QTL mapping and quantitative disease resistance in plants. Annu. Rev. Phytopathol. 34:479-501.

65. Zaitlin, D., DeMars, S., and Ma, Y. 1993. Linkage of rhm, a recessive gene for resistance to southern corn leaf blight, to RFLP marker loci in maize (Zea mays) seedlings. Genome 36:555-564.

66. Zeng, Z. B. 1994. Precision mapping of quantitative trait loci. Genetics 136:1457-1468. 